\title{
BUILD ABILITY DAN DESIGNABILITY SEBAGAI COMPETITIVE ADVANTAGE DI ERA PERDAGANGAN BEBAS
}

\author{
Indro Sulistyanto \\ Program Studi Arsitektur, Fakultas Teknik, Universitas Tunas Pembangunan Surakarta \\ Indrosty.utpska@gmail.com
}

\begin{abstract}
Abstrak
Perdagangan bebas ditandai dengan semakin tingginya mobilitas sumberdaya manusia, modal, teknologi, dan informasi. Komoditi yang diperdagangkan tidak lagi terbatas pada barang dan jasa yang secara telanjang dapat dinikmati oleh indera manusia, berupa perangkat-perangkat keras, tetapi akan mulai merambah pada perangkat lunak atau hak cipta intelektual.Dunia jasa konstruksi dituntut untuk dapat berperan dalam bentuk upaya penanganan proses rancang-bangun secara profesional. Salah satu kendali yang dapat digunakan dalam menunjang profesi dalam rancang-bangun di bidang jasa konstruksi adalah penerapan prinsip-prinsip perancangan dan pelaksanaan pembangunan dalam kesatuan proses membangun . Kegiatan rekayasa bangunan perlu kesiapan dari sejak studi kelayakan, perancangan, pengadaan barang, konstruksi, operasi dan pemeliharaan, dan lingkungan hidup-termasuk di dalamnya lingkungan binaan.Sebagai pemeran kunci dalam layanan jasa konstruksi, Arsitek merupakan salah satu tenaga ahli yang memberikan kontribusi menentukan di bidang rancang-bangun, dan diharapkan dapat secara profesional berperan pada perancangan dan rekayasa bangunan. Kemampuan profesional ini merupakan salah satu syarat penting untuk mampu bersaing secara bebas dalam era perdagangan bebas. Wawasan Arsitek yang secara profesional mampu menghayati dan menuangkan ide-gagasannya secara runtut dalam kesatuan proses pembangunan yang sistematik, diharapkan dapat menjadi modal dalam mengikuti persaingan bebas, khususnya pada proses perancangan dan rekayasa bangunan. Ada beberapa kelemahan yang sering terjadi dalam proses rancang bangun, berupa kurangnya wawasan Arsitek, baik dari sisi latar belakang pendidikan, pengalaman kerja, upaya pengembangan wawasan, variasi jenis pekerjaan, dan perannya dalam organisasi-profesi, yang mampu secara menyeluruh dan runtut menggunakan proses pembangunan melalui penerapan prinsip-prinsip perancangan dan rekayasa bangunan. Kondisi tersebut perlu diantisipasi, khususnya akan semakin meningkatnya persaingan dengan layanan jasa konstruksi asing, dengan tenaga ahli yang memiliki tingkat penguasaan informasi, teknologi, dan modal yang memiliki potensi besar untuk melakukan persaingan di era perdagangan bebas.
\end{abstract}

Kata kunci: Arsitek, Prinsip perancangan, Prinsip rekayasa

\begin{abstract}
Free trade is characterized by the increasing mobility of human resources, capital, technology and information. Commodities traded are no longer limited to goods and services that can be nakedly enjoyed by the human senses, in the form of hardware, but will begin to penetrate software or intellectual property rights. The world of construction services is required to play a role in the form of efforts to handle the design process. wake up professionally. One of the controls that can be used in supporting the profession in design in the field of construction services is the application of the principles of design and implementation of development in the unity of the building process. Construction engineering activities from the construction of the feasibility
\end{abstract}


study, design, procurement of goods, construction, operation and maintenance, and the environment, including the built environment. As a key actor in construction services, the Architect is one of the experts who provides decisive contributions in the design field. wake up, and are expected to be professionally involved in building design and engineering. This professional ability is one of the important requirements to be able to compete freely in the era of free trade. Architects' insights that are professionally capable of living and expressing their ideas in a coherent manner in the unity of a systematic development process, are expected to become capital in participating in free competition, especially in the process of design and construction. There are several weaknesses that often occur in the design process, in the form of architectural insights, both in terms of educational background, work experience, developmental insight, variations in types of work, and their role in professional organizations, which are capable of using the development process as a whole and coherent. - principles of building design and engineering. These conditions need to be anticipated, especially as competition will increase with foreign construction services, with experts who have a degree of mastery of information, technology, and capital that has great potential to conduct competition in the era of free trade.

Keywords: Architects, Design principles, Engineering principles

Perdagangan bebas ditandai dengan semakin tingginya mobilitas sumberdaya manusia, modal, teknologi, dan informasi (intelectual property). Komoditi yang diper-dagangkan tidak lagi terbatas pada barang dan jasa yang secara telanjang dapat dinikmati oleh indera manusia, berupa perangkat perangkat keras (hardwares), tetapi akan mulai merambah pada perangkat lunak (software) atau hak cipta intelektual (intelectual property).

Kondisi perdagangan yang bebas tanpa pembatas secara teritorial, dan jenis barang yang akan dikembangkan sebagai komoditi perdagangan, sebagaimana telah disepakati da-lam Uruguay Round/GATT tanggal 15 April 1994, yang tidak hanya mengatur Trade in Goods and Services, namun juga Invesment dan Intelectual Property Right dan terben-tuknya World Trade Organization (WTO), sebagai pengganti GATT (General Agreement in Trade and Tarriff). Indonesia sendiri telah meratifisir Uruguay Round 1994, dan akan memasuki era perdagangan bebas secara penuh pada Tahun 2020. Liberalisasi perda-gangan atau perdagangan bebas dapat diartikan adanya jaminan lalu-lintas barang, jasa, modal, dan manusia tanpa hambatan tarif, kuota, atau perlakuan khu-sus, berdasarkan prinsip MFN (Most Favored Nation). Semua negara akan diperlakukan sama dalam perda-gangan (equality to bussiness), tidak akan ada lagi pilih kasih atau diskriminasi, favoritisme, maupun hak istimewa (GSP dan kuota), dan dihapuskannya proteksi dalam segala bentuk.

\section{Unggulan Daya Saing}

Bagi Indonesia era perdagangan bebas berarti kemampuan untuk menjadikan komoditi ekspor yang memiliki unggulan daya saing tinggi (competitive advantage) dan tenaga ahli (intelectual property) Indonesia yang diharapkan mampu menjadi salah satu komoditi di pasar global, tidak terbatas untuk pasar dalam negeri, tetapi mampu menjadi experties di luar negeri. Perlu kesiapan yang benar-benar matang bagi tenaga ahli dan manajer yang secara profesional mampu memasuki era liberalisasi perdagangan secara penuh pada Tahun 2020, sehingga kita tidak terpaku menjadi konsumen, namun pengeks-por tenaga ahli dan manajer yang benar-benar siap bersaing di era perdagangan bebas. 
Rekayasa bangunan merupakan kegiatan jasa yang termasuk dalam era perdagangan bebas, sejak kesiapan dalam mela-kukan studi kelayakan (feasibility study), pe-rancangan (designengineering), pengadaan barang (procurement), rekayasa-konstruksi (construction), operasi dan pemeliharaan (operation and maintenance), dan lingkungan hidup-termasuk di dalamnya lingkungan bina-an (bionomic).

Salah satu kondisi yang harus diantisipasi oleh para pelaku industri konstruksi di Indonesia adalah dengan masuknya para in-vestor dan pengembang asing yang relatif mempunyai modal dan kemampuan (skill) tinggi. Pada saatnya persaingan para pelaku dunia jasa konstruksi akan meningkat dengan ketat, sehingga pada akhirnya hanya produk rancangan dan hasil rekayasa bangunan yang berkualitas tinggi saja yang akan mampu ber-saing.

Arsitek merupakan salah satu tenaga ahli yang memberikan kontribusi menentukan di bidang rancang-bangun, dan diharapkan dapat secara profesional berperan pada peran-cangan dan rekayasa bangunan. Kemampuan profesional ini merupakan salah satu syarat penting untuk mampu bersaing secara bebas dalam era perdagangan bebas. Wawasan Arsitek yang secara profesional mampu meng-hayati dan menuangkan ide dan gagasannya secara runtut dalam kesatuan proses pembangunan yang sistematik, diharapkan dapat menjadi modal dalam mengikuti persaingan bebas, khususnya pada proses perancangan dan rekayasa bangunan.

Kelemahan yang sering terjadi dalam proses rancang bangun adalah kurangnya wa-wasan Arsitek yang mampu secara menye-luruh dan runtut menggunakan proses pemba-ngunan yang terlanjutkan. Hasil rancangan tidak cukup hanya perancangan (design) na-mun harus sampai pada rekayasa (engineering).
Proses perancangan juga harus memperhatikan proses-proses yang mendahu-lui maupun akan berlangsung di depannya dalam satu kesatuan strategi dan tahapan pembangunan.

Tanpa dukungan kemampuan dan kualitas sumberdaya manusia yang menguasai ilmu pengetahuan dan teknologi, kreatif, dan inovatif, negara kita tidak akan mampu memasuki pasar global dan era perdagangan bebas di Abad XXI, oleh karena baik produkproduk alam dan sumberdaya manusia yang murah, tidak lagi dapat diandalkan sebagai sumberdaya strategis yang mampu berperan sebagai andalan komparatif maupun unggulan daya saing, dan kuncinya terletak pada tenaga ahli yang benar-benar di dukung oleh kemampuan untuk menguasai ilmu pengetahuan dan teknologi.

\section{Esensi Arsitek dalam Perdagangan Bebas Ekonomi}

Arsitek merupakan investasi sumberdaya manusia dapat dilakukan melalui outsourcing dari ekonomi global, ditingkat mikro memiliki daya saing yang tercermin dalam efisiensi tinggi, disiplin finansial, harga stabil, memudahkan modal masuk (outsourcing capital) dan memperoleh keun-tungan dari perdagangan internasional. Dam-pak ekonomi stabil di tingkat makro, tidak mudah tergoncang oleh goncangan pasar du-nia, dan mudah menarik modal luar negeri (direct invesment-PMA).

Mengamati ekonomi dan teknologi yang berkembang sampai saat ini, adalah lan-dasan untuk mengamati bentuk yang akan terjadi dimasa mendatang. Bisnis kecil, di manapun juga di Indonesia tampaknya akan berkembang sebagai ladang mayoritas bagi ke-hidupan negara. Kemajuan teknologi dan semakin tingginya tingkat kesejahteraan masyarakat, membuka lebih banyak 
peluang bagi pengembangan pangsa pasar baru. Kondisi ini tentunya dapat pula terjadi di Indonesia termasuk perkembangan jasa kons-truksi. Perkembangan teknologi, khususnya yang berbasis komputer, telah tumbuh semakin pesat dan membawa kita semakin maju. Pengetahuan dan teknologi informasi telah menjadi raja atau primadona, sehingga tercipta peluang-peluang bisnis yang semakin banyak dan bervariasi.

\section{Arsitek sebagai Komoditi Intelektual di Bidang Konstruksi}

Arsitek sebagai bagian dari tenaga ahli di bidang jasa konstruksi diharapkan dapat menjadi komoditi intelektual (intelectual property) yang potensial dalam era perdagangan bebas, apabila Arsitek mampu berperan sebagai sumberdaya manusia yang memeiliki kualifikasi standar internasional dengan sertifikasi internasional, sehingga memiliki mobilitas untuk bekerja dan menjual jasa kemampuan intelektual dan hasil kar-yanya di pasar global. Apabila sejak dini Arsitek sebagai pemeran ahli jasa konstruksi tidak mampu berperan secara profesional, se-bagai human capital yang memiliki intelectual property yang mampu berkarya secara kreatif dan inovatif, maka sangat mungkin pasar profesi Arsitek pada industri jasa konstruksi, khususnya di dalam negeri akan dibanjiri oleh tenaga profesi Arsitek dari luar negeri tanpa hambatan, sebagai konsekuensi dari komoditi pasar global.

Upaya untuk dapat mengha-silkan Arsitek sebagai pemeran ahli pada bidang jasa konstruksi yang profesional de-ngan kualifikasi yang memenuhi standar internasional (WTO), memerlukan outsourcing strategy, untuk memperoleh masukan seba-nyak mungkin studi perbandingan dari luar negeri, dalam rangka transfer of technology and transfer of knowledge.
Apabila Arsitek tidak ikut berperan dalam perubahan yang telah dan akan terus terjadi, maka lingkungan kehidupan profesinya akan terpenuhi oleh masa depan yang penuh dengan ketidak pastian, atau masuk kedalam lingkungan masyarakat profesi yang dibuat mudah terkejut (future shock). Sementara profesi sebagai seorang Arsitek belum menguasai ilmu pengetahuan dan teknologi dalam ukuran keahlian dan muatan padat intelectual property, maka upaya memperoleh sumber informasi dari luar perlu ditingkatkan, agar pada Tahun 2020 profesi Arsitek telah benar-benar mampu masuk dalam lingkungan liberalisasi dan perdagangan bebas.

Arsitek sebagai pemeran ahli yang pada saatnya diharapkan mampu berperan secara profesional dalam bidang jasa kons-truksi, harus memperhatikan adanya kecen-derungan sebagai berikut:

a. Kemungkinan terjadinya perubahan yang begitu cepat, sebagai dampak dari kema-juan ilmu pengetahuan dan teknologi; yang canggih pada hari ini kemungkinan akan menjadi ketinggalan pada kesem-patan berikutnya. Akan terjadi proses perkembangan hasil karya yang menjadi lebih baik, canggih, bermutu, dan dengan investasi yang lebih murah dibandingkan hasil karya sebelumnya. Kondisi ini akan diikuti oleh kecanggihan precission equipment computers, electronics, telecomunications, automotive, dan peralatan canggih lainnya menunjukkan perubahan yang begitu cepat; sebagai hasil dari product of human intelectual property.

b. Semakin tingginya faktor ketidak pastian masa depan (uncertainties). Tidak akan terjadi suatu rencana yang pelaksanaan-nya berjalan dengan mulus-linier-naik, selalu diperlukan adaptasi dan penye-suaian agar sasaran optimal dapat dicapai. 
Akan terjadi perubahan yang menerus, dan terjadi kondisi adanya kepastian dalam ketidak pastian.

c. Dalam era informasi yang semakin glo-bal, dituntut keberadaan Arsitek sebagai sumberdaya manusia unggulan, baik dalam arti competitive advantage maupun comperative advantage. Arsitek harus dapat diberdayakan sehingga memiliki unggulan dalam keahlian (profesional), baik dari sisi mutu hasil karya, desain, pengembangan wawasan, dinamis, ino-vatif, dan kreatif.

d. Dalam era informasi global, ijazah formal (educated people) akan menjadi tidak ber-arti tanpa diikuti dengan pelatihan, sehingga memenuhi syarat sebagai seo-rang profesional, tenaga yang ahli dalam bidangnya.

Arsitek sebagai tenaga ahli profesional (knowledge worker) harus mampu bekerja secara multi disiplin. Arsitek bukan sebagai dewa, peran Arsitek akan lebih tepat disebut sebagai mitra di dalam hubungan kerja di bidang jasa konstruksi, sebab untuk keahlian tertentu seorang tenaga ahli memiliki kelebihan tersendiri, yang sangat mungkin tidak dimiliki oleh tenaga ahli yang lain.

Dalam menghadapi persaingan global kedudukan etika dalam profesi Arsitek men-jadi sangat penting, khususnya peran Arsitek sebagai pelaku bisnis di bidang jasa kons-truksi, akan menjadi tolok ukur utama ke-berhasilan dalam melakukan bidding of business. Kode etik dalam melakukan bisnis diharapkan dapat benar-benar dihayati, sadar akan kedudukan dan pentingnya mendudukkan Arsitek dalam suatu etika bisnis untuk dapat melakukan persaingan yang sehat.
Kebutuhan akan etika bisnis dalam berprofesi semakin terlihat bagi setiap pelaku bisnis yang berfikir dalam perspektif jangka panjang. Sebaliknya bagi mereka yang hanya berfikir untuk mencari keuntungan yang sebesarbesarnya, merupakan pikiran dalam perspektif jangka pendek, sehingga kebutuhan akan penciptaan standar etika tidak begitu dirasakan.Dalam jangka panjang, binis tanpa etika profesi Arsitek tidak mungkin akan ber-hasil, sebab hal itu akan sangat terkait dengan kepentingan suatu kegiatan usaha, lingkungan setempat, kepentingan nasional, dan koordinat-kordinat internasional. Adanya kepatuhan akan standar etika profesi Arsitek dalam melakukan kegiatan bisnis, seperti kejujuran, akan me-numbuhkan rasa saling percaya antar pelaku bisnis, sehingga tumbuh kepentingan semua pihak yang terkait dalam lingkaran kegiatan bisnisnya. Kejujuran merupakan salah satu prasyarat keberhasilan bisnis, karena kejujuran dan sikap etis pada umumnya, tidak sekedar tuntutan moral, namun lebih merupakan tun-tutan efisiensi bagi bisnis itu sendiri.

Tantangan yang dihadapi oleh dunia profesi Arsitek di Indonesia adalah bagaimana menyeimbangkan antara idealisme dengan tuntutan para pelaku bisnis yang sering menge-sampingkan norma-norma etika profesi Arsi-tek demi mencapai tujuan utama, menye-babkan para pelaku bisnis sering terjebak mencari jalan pintas, sehingga menghalalkan segala cara untuk mencapai tujuan tersebut.Kegiatan bisnis yang mengabaikan etika profe-si akan menciptakan keresahan moral pada setiap pelaku yang terlibat di dalamnya, dan dapat menghambat kegairahan dalam suatu persaingan yang sehat, sehingga dalam suatu lingkup kegiatan bisnis dapat terjadi penu-runan kualitas dan kuantitas dari suatu hasil karya. 
Kode etik profesi Arsitek dalam kegi-atan bisnis diperlukan sebagai panduan untuk me-nerapkan nilai-nilai fundamental dalam masyarakat luas, meliputi hak dan kewajiban, keadilan, persamaan, maslahat dan kebajikan, kesetiaan dan kejujuran dalam dunia bisnis. Dengan demikian kode etik profesi dalam melakukan bisnis perlu dihayati oleh semua Arsitek, dengan dipagari oleh moral dan akhlak yang luhur, sehingga moral setiap Arsitek profesional dalam melakukan bisnis akan melindungi kegiatan bisnisnya dari kesulitan.

Arsitek sebagai tenaga ahli dalam bidang jasa konstruksi, ideal apabila meme-nuhi standar, profesional, dan memiliki inte-gritas tinggi dalam bidangnya, yang bermuara pada etika. Dalam menghadapi era pasar global, keadaan ini akan memberi konsekuensi Arsitek sebagai profesionalisme di bidang jasa konstruksi dengan penguasaan aspek teknis, dan persoalan-persoalan yang muncul pada kegiatan jasa konstruksi serta kemampuan mengikuti perkembangan teknologi yang mendukung kegiatan jasa konstruksi. Untuk itu dituntut berbagai syarat yang bersifat comprehensive and integrated, yaitu etika yang lengkap dan terpadu serta saling terkait antara satu unsur dengan unsur yang lain, meliputi: sensitivity, prudence, expertise, capability, integrity, experience, communicative, responsibility, entrepeneur, double size, intelegence, and tolerance.

\section{Strategi Build Ability dan Designability sebagai Competitive Advantage}

Model input-process-output dari Benyamin Handler pada dasarnya dapat berperan sebagai body of knowledge yang menjelaskan bentuk umum dari seluruh kegi-atan membangun projek, agar setiap pelaku yang terlibat di dalam projek tidak kehilangan arah untuk menghadapi kerumitan masalah dan perkembangan yang terjadi pada setiap bagian projek.

Benyamin Handler (1993),
menyusun proses tersebut melalui
operation research (OR) sebagai rujukan.
OR pada dasarnya me-nekankan kepada proses pengambilan kepu-tusan. Sebuah projek sarana (facility), pada dasarnya adalah sebuah sistem fisik yang besar dan terdiri dari berbagai sub sistem. Sub sistem terdiri dari komponen-komponen fisik yang mempunyai fungsi sendiri dan terko-ordinasi, sehingga secara keseluruhan sistem besar tersebut dapat berfungsi dengan sem-purna untuk suatu tujuan tertentu. Menurut Benyamin Handler kita tidak boleh meman-dang model input-process-output hanya berlaku bagi bangunan gedung, namun berlaku pada semua projek sarana (Pedju, 1993).

Pada umumnya, pihak yang paling berkepentingan dalam pembangunan suatu projek adalah Pemilik Projek. Pemilik Projek akan terlibat sejak langkah pertama hingga langkah terakhir, sejak studi kelayakan dite-tapkan, sampai dengan tahap bionomik, dan bahkan harus memikirkan dan mempertang-gung jawabkan sampai dengan tahap pemusnahan. Sehingga dengan demikian usahanya dapat benar-benar berjalan dan memuaskan baik secara manusiawi maupun secara ekonomis.

Dalam kegiatan untuk membangun projek, Pemilik Projek harus dapat mencip-takan sebuah organisasi khusus untuk meng-urus pembangunan projek, sejak awal hingga projek dapat dikonstruksikan dan selanjutnya dapat beroperasi sesuai dengan yang direncanakan. Tanggung jawab organisasi khusus ini adalah mengelola dan mengendalikan se-luruh proses pembangunan projek melalui project management. Pemilik Projek dapat 
menciptakan organisasi projek dengan meng-gunakan tenaga ahli dari dalam (internal) lembaganya atau menggunakan tenaga ahli dari luar (eksternal) dengan fasilitas yang dimiliki, atau suatu organisasi projek gabung-an internal dan eksternal.

\section{Konsep Perancangan dan Rekayasa (Designability and Buildability)}

Strategi dalam pembangunan-projek, dapat diukur dari penerapan konsep perancangan dan rekayasa-konstruksi (design and build-design and construction concept) bagi setiap pihak yang terlibat di dalam proses pembangunan. Penerapan konsep tersebut diharapkan dapat memberi arah yang jelas baik bagi kepentingan Pemilik Projek (Owner), Perancang (Design-Engineer, khususnya Arsi-tek), Pelaksana Pekerjaan (Contractors), da-lam kasus penelitian ini keterlibatan Arsitek secara langsung dalam tahap perancangan dan rekayasakonstruksi, serta peran konsep perancangan dan rekayasa dalam menunjang keber-hasilan projek.

Konsep perancangan dan rekayasa merupakan solusi dalam menyelesaikan berba-gai persoalan yang dapat terjadi baik pada tahap perancangan maupun rekayasa. Untuk itu dalam penelitian diupayakan memperoleh informasi dari responden, tentang: diperlukan-nya konsep design and build dalam perancang-an dan rekayasa, seberapa jauh Arsitek harus memahami konsep tersebut, pandangan ten-tang konsep design and build sebagai solusi terbaik dalam proses perancangan dan reka-yasa, dan pandangan tentang kesatuan antara designability dengan buildability.

Variabel proses perancangan tersusun atas prinsip-prinsip yang akan mendukung proses perancangan, sehingga seorang Arsitek mampu menjadi fasilitator bagi terjadinya proses komunikasi dari suatu gagasan menjadi bentuk rancang-bangun yang diharapkan (Juwono, 1997). Prinsip-prinsip dalam proses perancangan terdiri atas:

a. Setiap projek harus memperhitungkan dasar-strategi pembangunan

b. Dasar-dasar konsep perancangan sebagai penentu keberhasilan proses perancangan berikutnya

c. Program-program perancangan sebagai landasan proses perancangan

d. Perancangan tidak hanya design namun juga engineering

e. Pengetahuan dan pengalaman perancang-an dalam jenis projek tertentu, sebagai penentu ketajaman hasil perancangan

f. Proses perancangan perlu didukung oleh kemampuan organisasi, fasilitas, dan modal

g. Proses pembuatan rancangan harus meli-batkan ahli-ahli rancang-bangun secara multi disiplin

h. Limitasi yang berupa kondisi lingkungan nyata di sekitar projek akan mempeng-aruhi proses perancangan

i. Peraturan-peraturan tentang rancangbangun akan mempengaruhi dan meng-ikat proses perancangan

j. Standar dan kriteria perancangan sepe-nuhnya mempengaruhi dan mengikat pro-ses perancangan

k. Umpan balik terhadap kriteria kelayakan pembangunan akan meningkatkan akurasi proses dan hasil rancangan

1. Proses perancangan harus berjalan secara runtut, lengkap, dan spesifik.

Hasil perancangan tersusun atas prinsip-prin-sip yang akan menentukan tingkat akurasi perancangan untuk dapat 
digunakan sebagai acuan bagi proses berikutnya, khususnya pengadaan dan rekayasa-konstruksi. Prinsip-prinsip yang akan mendukung akurasi hasil perancangan, terdiri atas:

a. Tujuan akhir perancangan mengikat dan mempengaruhi proses perancangan

b. Gambar-gambar rencana harus lengkap, terinci, dirancang spesifik dan jelas.

Sedangkan prinsip-prinsip rekayasa
yang telah dilakukan melalui pertimbangan rekayasa, proses rekayasa, dan keluaran reka-yasa. Pertimbangan rekayasa tersusun atas prinsip-prinsip yang selayaknya dila-kukan, sehingga seorang Arsitek mampu memberi pertimbangan yang memenuhi kaidahkai-dah dalam melakukan rekayasa atas hasil peran-cangan yang telah dihasilkan. Pada sisi lain dari hasil perancangan, arsitek juga dapat memberi pertimbangan tentang berbagai ke-mungkinan pengadaan sumberdaya yang telah dipersiapkan untuk kelancaran proses rekayasa. Prinsip-prinsip yang selayaknya dipertimbangkan dalam rekayasa, terdiri atas:

a. Rekayasa-konstruksi, harus mempertimbangkan tahap pengadaan sumberdaya, khususnya komponen yang akan digu-nakan

b. Peran kelengkapan, ketelitian gambar dan spesifikasi dari setiap bagian peran-cangan akan menentukan tingkat akurasi pelaksanaan

c. Faktor-faktor produksi konstruksi mutlak menjadi pertimbangan di dalam pelak-sanaan.

Proses rekayasa tersusun atas prinsip-prinsip yang akan mendukung proses rekayasa, sehingga Arsitek mampu berperan sebagai me-diator yang baik, untuk menjaga kon-sistensi setiap tahapan pembangunan, khususnya dari tahap perancangan, pengadaan sumberdaya, dan rekayasa-konstruksi, sehingga pada sa-atnya dapat dioperasikan dengan baik.Prinsip-prinsip dalam proses rekayasa terdiri atas:

a. Proses pengkonstruksian dan perakitan merupakan kesatuan projek secara fisik

b. Keberhasilan perancangan dapat diukur dari fungsi, operasi, pemeliharaan, dan pengendalian lingkungan yang sempurna

c. Restriksi selama proses pengkonstruksian adalah: tujuan fisik, kondisi yang ada, syarat dan peraturan konstruksi yang ha-rus dipenuhi

d. Pertimbangan akses pencapaian menuju lokasi projek

e. Pengenalan situasi, kondisi, dan potensi tapak

f. Pentahapan distribusi dan penyimpanan material

g. Proses seleksi terhadap spesifikasi peng-gunaan untuk masing-masing material yang akan dikonstruksikan

h. Memperhatikan perakitan semua kompo-nen bangunan yang akan digunakan

i. Pemenuhan urutan operasional secara praktis dan efisien bagi seluruh bagian projek yang akan dilaksanakan

j. Pemasangan pagar lokasi

k. Merancang waktu minimum untuk peker-jaan-pekerjaan khusus, terutama pada pekerjaan bawah tanah dan pekerjaan-pe-kerjaan yang banyak mengandung resiko

1. Menentukan keahlian sumberdaya manu-sia yang akan dilibatkan di projek

m. Merancang pembangunan yang aman untuk daerah yang beresiko tinggi 
Ada korelasi yang menentukan dalam projek yaitu wawasan arsitek terhadap strategi danpemahaman terhadap tahapan pemba-ngunan yang terdiri atas: strategi dan pema-haman tahapan pembangunan, penerapan prinsip-prinsip perancangan, dan penerapan prinsip-prinsip rekayasa. Korelasi antara wa-wasan Arsitek yang tersusun atas data-data identitas dan latar belakang responden, dengan prinsipprinsip perancangan (designability) sehingga diharapkan akan didapatkan gambaran seberapa besar pengaruh yang ada pada tingkat wawasan Arsitek terhadap pertimbangan, pro-ses, dan keluaran pada tahap perancangan.

Sedangkan korelasi antara wawasan Arsitek yang tersusun atas data-data identitas dan latar belakang responden, dengan prinsip-prinsip rekayasakonstruksi (buildability), se-hingga diharapkan akan didapatkan gambaran adakah pengaruh antara tingkat wawasan Arsi-tek terhadap pertimbangan, proses, dan hasil pada tahap rekayasa-konstruksi. Korelasi antara wawasan Arsitek yang tersusun atas data-data identitas dan latar belakang profesi Arsitek dengan prinsipprinsip rekayasa-konstruksi (buildability), akan didapatkan gambaran adakah pengaruh antara tingkat wa-wasan Arsitek terhadap pertimbangan, proses, dan hasil pada tahap rekayasa-konstruksi.

\section{Implikasi Hasil Studi terhadap Kebijakan Pemerintah dan Asosiasi Profesi Arsitek}

Implikasi peran wawasan arsitek sebagai komoditi intelektual dalam pemba-ngunan terlanjutkan diharapkan dapat digunakan sebagai upaya dalam menuju kemajuan dan kemandirian setiap pelaku jasa konstruksi, khususnya Arsitek melalui pening-katan profesionalisme dan perbaikan iklim usaha. Kondisi ini diharapkan dapat dianti-sipasi baik oleh Pemerintah sebagai penentu kebijakan, maupun Asosiasi Profesi di bidang jasa konstruksi, khususnya Arsitek dalam wadah asosiasi profesi Ikatan Arsitek Indonesia (IAI).

Sebagaimana disampaikan oleh Ginanjar (1994): Berbicara mengenai usaha jasa konstruksi tidak dapat tidak kita harus berbicara tentang sumberdaya manusia. Setiap pelaku jasa konstruksi akan memberi peran yang amat besar dalam membangun kemajuan dan kemandirian bangsa. Implikasinya diharapkan dapat digunakan sebagai upaya dalam menuju kemajuan dan kemandirian setiap pelaku jasa konstruksi, khususnya Arsitek melalui peningkatan profesional-isme dan perbaikan iklim usaha. Kondisi ini diharapkan dapat diantisipasi baik oleh Pemerintah sebagai penentu kebijakan, maupun Asosiasi Profe-si di bidang jasa konstruksi, khususnya Arsitek dalam wadah asosiasi profesi Ikatan Arsitek Indonesia (IAI).

Berbicara mengenai usaha jasa konstruksi tidak dapat tidak kita harus berbicara tentang sumberdaya manusia. Setiap pelaku jasa konstruksi akan memberi peran yang amat besar dalam membangun kemajuan dan keman-dirian bangsa.Sangat mungkin projek yang sarat dengan teknologi akan memberi dampak langsung pada jenis teknologi yang akan diterapkan dan sumberdaya manusia (tenaga ahli profesional) yang akan dilibatkan di dalamnya. Kondisi ini akan memberi dam-pak yang sangat besar, apabila ditambah dengan sumber investasi asing bagi pembangunan/projek yang pada saatnya akan "membanjiri" projek-projek di Indonesia. Antisipasi ke depan dalam era perdagangan bebas mendatang, khususnya bagi kegiatan usaha di bidang jasa konstruksi harus menjadi pertimbangan serius baik dari pemerintah, selaku penentu kebijakan tentang spesifikasi projek yang memenuhi kelayakan investasi di Indonesia, dan sumberdaya manusia yang 
secara profesional memenuhi kualifikasi internasional dalam menangani projekprojek khususnya yang sarat dengan inovasi dan teknologi masa depan. Menjadi tugas asosiasi profesi di bidang jasa konstruksi, IAI bagi Arsitek untuk dapat memberi rekomendasi tentang profesionalisme Arsitek dalam menangani kegiatan rancang-bangun di Indonesia.

\section{Implikasi terhadap Kebijakan Pemerintah}

Setiap pelaku/praktisi pada bidang jasa konstruksi, termasuk di dalamnya Arsitek, akan memberi peran yang sangat besar dalam membangun kemajuan dan kemandirian bangsa. Kemajuan bangsa akan dihasilkan oleh pembangunan yang berhasil, dan keberhasilan pemba-ngunan lebih banyak ditentukan oleh hasil kerja setiap pemeran pada bidang jasa konstruksi, karena pembangunan akan berhasil apabila dipersiapkan secara baik dan dirancang secara tepat. Banyak pembangunan tidak atau kurang berhasil mencapai sasaran karena perencanaan yang kurang baik.

Kondisi yang sangat penting dan strategis adalah peran Arsitek dalam melaku-kan proses perancangan dan antisipasinya terhadap rekayasa (pelaksanaan) projek. Perlu menjadi pertimbangan dalam hal penentuan kebijakan (termasuk oleh pemerintah) untuk menentukan jasa konsultan, kontraktor, pro-duksi dari sumberdaya yang dimiliki di dalam negeri atau luar negeri. Spesifikasi yang disusun sejak tahap studi kelayakan, peran-cangan, pengadaan sumberdaya, konstruksi, operasi dan pemeliharaan, dan bionomik, akan menentukanapakah akan dimungkinkan menggunakan produk impor atau menggu-nakan produk ekspor.

Arsitek diharapkan dapat menjadi pemeran utama dalam membangun keman-dirian di bidang layanan jasa konstruksi. Melalui hasil perancangan dan rekayasa pem-bangunan, sangat dimungkinkan untuk meng-arahkan agar pembangunan dilaksanakan de-ngan kemampuan tenaga ahli yang profesional dari dalam negeri, yang menjadi hakekat dari kemandirian. Berkaitan dengan itu kebijakan pemerintah akan menentukan seberapa besar kepercayaan diberikan kepada Arsitek dan pemeran dalam layanan jasa konstruksi yang lain untuk melaksanakan projek pembangunan termasuk, dan terutama projek-projek berskala besar yang padat ke-trampilan dan padat teknologi. Melalui peluangpeluang tersebut sangat dimungkinkan untuk membangun ke-kuatan dan kualitas profesionalisme setiap pemeran di dalam layanan jasa konstruksi nasional, dan sekaligus mengarahkan peng-gunaan produk-produk teknologi Bangsa Indonesia.

Dari sisi peran Arsitek, dapat ditunjuk-kan, bahwa dengan kesempatan yang dib-rikan, Arsitek dan pemeran jasa konstruksi yang lain, secara profesional mampu melak-sanakan projek-projek dengan skala besar dan padat dengan ketrampilan dan teknologi. Bukan hanya pemerintah yang harus memberi kepercayaan kepada jasa konstruksi nasional, namun juga perusahaanperusahaan swasta nasional perlu memberi prioritas kepada jasa konstruksi nasional dan ahli-ahli konstruksi dari dalam negeri.

Masih dirasakan adanya kelemahan Arsitek profesional dan dapat terjadi tenaga ahli dalam bidang jasa konstruksi yang lain dalam menjalankan profesinya. Kon-disi ini dapat terlihat dari latar belakang pendidikan, latar belakang pengalaman, latar belakang pekerjaan, upaya pengembangan wawasan, dan latar belakang organisasi profesinya, apabila dikaitkan dengan pemahaman dan penerapan prinsip-prinsip perancangan dan reka-yasa yang telah dilakukan. 
Dalam kenyataan sehari-hari, sering terlihat kurang adanya upaya untuk memperkuat profesional dan mengikuti perkembangan teknologi, pada-hal teknologi menjadi nafas dari keseluruhan tahapan pembangunan, khususnya perancang-an dan rekayasa.Arsitek dan setiap pemeran dalam layanan jasa konstruksi yang lain, harus selalu berupaya untuk membangun diri. Kita pada saatnya tidak akan dapat lagi mengandalkan proteksi dan prioritas yang diberikan oleh pemerintah dan perusahaan swasta nasional yang lain. Da-lam projek-projek yang dibiayai bantuan luar negeri, setiap pelaku layanan jasa konstruksi harus mampu bersaing dengan layanan jasa kons-truksi asing. Dalam rangka meningkatkan kepercayaan pemerintah dan perusahaan swasta nasional akan layanan jasa konstruksi nasional, perlu diupayakan peningkatan efisiensi secara ekonomis pada setiap tahapan pembangunan, upaya terjaganya lingkungan alam dan binaan, termasuk di dalamnya lingkungan sosial di sekitar projek pemba-ngunan.

\section{Implikasi terhadap Asosiasi Profesi Arsitek}

Menghadapi persaingan di era perdagangan bebas, formalitas seorang Arsitek profesional, dan pemeran jasa konstruksi yang lain ditunjukkan dengan diakuinya kadar profesionalisme oleh asosiasi profesi. Bagi Arsitek di Indonesia, formalitas tersebut ditunjukkan dengan keanggotaan pada Ikatan Arsitek Indonesia (IAI), yang diawali sebagai anggota biasa, dan akan meningkat menjadi anggota profesional dengan hak menyandang gelar IAI apabila telah dipenuhinya segala persyaratan profesi Arsitek melalui kursus (khususnya kode etik profesi), menunjukkan hasil karya yang dapat dinominasikan, dan rekomendasi terhadap kelayakan untuk menjalankan praktek profesinya oleh anggota profesional yang dipandang senior.

Kesadaran akan keanggotaan profesi IAI belum disadari dengan baik sebagai bagian dari kekuatan persaingan mendatang. Keeng-ganan menjadi anggota profesi ini dapat dimaklumi, mengingat antara sisi manfaat (hak) dan kewajiban sebagai anggota belum menunjukkan kesepadanan. Banyak dari Arsitek profesi, dan kemungkinan pemeran jasa konstruksi yang lain belum dan tidak melihat manfaat yang dapat diraih dari keanggotaan profesi ini.

Pada sisi lain kode etik profesi yang diharapkan menjadi tulang punggung di dalam menjalankan profesi Arsitek belum sepenuh-nya dapat berjalan dalam setiap layanan jasa konstruksi. Sebagaimana disampaikan oleh Suseno (1994), etika profesi jangan dianggap sebagai tempelan belakangan pada keahlian profesional, melainkan etika profesi termasuk kompetensi seorang profesional. Setiap profesi membawa tantangan-tantangan etis yang khas. Seseorang baru benarbenar profesional apabila dapat memecahkan masalah-masalah etis yang diha-dapinya dalam profesinya secara kompeten. Perlu disadari bahwa dalam setiap menjalankan profesinya akan muncul masalah-ma-salah etis yang menuntut seku-rang-kurangnya by default: mengabaikan segi etis akan memperlihatkan diri sebagai pengambilan sikap etis negatif.

Etika termasuk dalam efisiensi profesi. Tanpa standar-standar etis profesionalitas sen-diri akan mengalami penurunan kualitas. Dua segi dasar dalam menjalankan etika profesi; sebagai Arsitek yang perlu diperhatikan, yaitu segi moral pribadi orang profesional, dan segi norma-norma obyektif etika profesi yang ber-sangkutan, sebagai seorang profesional yang bermoral mencari orientasinya. Segi subyektif; dari profesional diharapkan, tumbuh 
kesadaran kedudukannya sebagai manusia yang integer. Karena syarat keberhasilan dalam memberikan layanan jasa konstruksi adalah adanya saling kepercayaan. Dengan demikian tercermin su-atu kondisi seorang profesional merupakan pribadi yang jujur, bertekad untuk tidak pernah mela-kukan penipuan, dan tidak menyeleweng dari standarstandar yang diyakini.

\section{Kesimpulan}

Kesimpulan yang dapat ditarik dari kegiatan penelitian ini meliputi: identitas dan latar belakang Arsitek, strategi dan pemahaman terhadap tahapan pembangunan, penerapan prinsip-prinsip perancangan, penerapan prin-sip-prinsip rekayasa, keterkaitan wawasan Arsitek terhadap tahapan pembangunan, keterkaitan wawasan Arsitek terhadap prinsip-prinsip perancangan, keterkaitan wawasan Arsitek terhadap prinsip-prinsip rekayasa, dan implikasinya terhadap kebijakan pemerintah maupun asosiasi profesi.

a. Layanan jasa konstruksi merupakan arah yang tepat bagi pengembangan usaha dan profesi Arsitek

b. Tanpa mengabaikan tahapan pembangun-an yang lain, posisi tahap perancangan dan rekayasakonstruksimenjadi bagian yang paling diminati dan menentukan dalam melihat perkembangan wawasan Arsitek sebagai seorang profesional

c. Upaya pengembangan wawasan Arsitek di bidang rancang-bangun, perlu diting-katkan melalui media yang efektif dalam memberi informasi terkini tentang perkembangan teknologi, khususnya peran-cangan dan rekayasa, terutama melalui media jurnal

d. Perlu difikirkan secara serius tentang rekomendasi keanggotaan dalam organi-sasi profesi (IAI), sebagai bagian integral atas kemampuan profesional sebagai Arsitek dalam menghadapi persaingan di era perdagangan bebas

e. Bagi kepentingan pemilik projek (owner), perancang dan pelaksana, konsep peran-cangan dan rekayasa mampu memberi peluang yang menguntungkan

f. Ada kecenderungan sebagian Arsitek da-lam menjalankan profesinya belum me-mahami konsep perancangan dan reka-yasa sebagai kesatuan konsep dari keseluruhan proses membangun

g. Kecenderungan Arsitek lebih berpeluang dalam memberi layanan di bidang jasa konstruksi, khususnya pada tahap pra perancangan, perancangan, dan rekayasa

h. Profesi Arsitek sebagai perancang dan rekayasa sangat diuntungkan dengan pemanfaatan konsep perancangan dan rekayasa

i. Arsitek profesional cenderung memper-timbangkan tahapan operasi, pemeli-haraan, lingkungan hidup, dan lingkungan binaan sebagai pertimbangan utama. Kondisi ini menentukan proses dan hasil perancangan selanjutnya, mengingat makna utama dari hasil perancangan adalah pertimbangan tersebut

j. Dari sisi kepentingan projek, tidak seluruh projek menurut pertimbangan Arsitek selaku profesi di bidang rancang-bangun, harus melalui studi kelayakan, namun pertimbangan kelayakan dalam pembangunan tetap menjadi bagian yang harus dipertimbangkan dalam perancang-an maupun rekayasa

k. Ada kecenderungan para Arsitek profesi-onal mengarah pada penanganan projek yang kurang 
kompetitif, pertimbanganpertimbangan utama yang dilakukan cenderung pada proses yang tidak memerlukan pertimbangan keruntutan proses pembangunan yang menyeluruh

1. Ada kecenderungan Arsitek profesional mengutamakan design daripada engineering, kondisi ini menunjukkan kesederhanaan dalam proses perancangan maupun rekayasa

m. Arsitek profesional cenderung mendahu-lukan hasil rancangan, dibandingkan dengan pertimbangan untuk mengupaya-kan akurasi hasil perancangan

n. Faktor-faktor produksi konstruksi, cende-rung menjadi pertimbangan utama bagi Arsitek profesional dalam melakukan per-timbangan rekayasa

o. Arsitek profesional cenderung yakin atas hasil perancangan untuk dapat dimple-mentasikan

p. Dalam melakukan proses rekayasa, Arsi-tek profesional cenderung memberi per-timbangan utama pada lokasi projek, mengatur perakitan dan distribusi komponen dan material projek, dan menentukan keahlian sumberdaya (tenaga ahli) yang akan dilibatkan di dalam projek

q. Untuk memberi hasil yang maksimal dari proses rekayasa, ada kecenderungan Arsitek profesional memberi pertimbang-an awal pada kondisi, lokasi, dan potensi projek, khususnya berkaitan dengan penempatan alat-alat pendukung projek, ketelitian dan akurasi perencanaan dan pelaksanaanya di lapangan, serta perenca-naan perulangan pada beberapa komponen bangunan melalui studi modul dan unit fungsi

r. Terdapat signifikansi yang erat antara latar belakang pendidikan dengan pertim-bangan perancangan, artinya seorang Arsitek profesional dengan latar belakang pendidikan yang sesuai dengan ciri profesionalismenya, akan mampu mem-berikan pertimbangan yang lebih baik dalam setiap tahapan pembangunan

s. Ada kecenderungan latar belakang pendidikan seorang Arsitek akan sangat menunjang dalam memberi pertimbangan dan proses pembangunan dengan baik, dan tidak memberi perhatian yang ber-lebihan pada hasil akhir perancangan. Artinya menurut pertimbangan Arsitek, hasil perancangan yang diharapkan (sesuai dengan yang direncanakan) hanya dapat dicapai melalui pertimbangan dan proses perancangan yang baik

t. Tingkat kemampuan dalam memberikan pertimbangan rekayasa, cenderung ditentukan oleh latar belakang profesi dari organisasi profesi (IAI, upaya dalam mengembangkan wawasan, dan latar belakang pengalaman Arsitek

u. Setiap pemeran dalam layanan jasa konstruksi (termasuk di dalamnya Arsitek), harus siap secara profesional untuk bersaing, baik pada projek-projek pemerintah, perusahaan swasta nasional, maupun kemungkinan investor asing.

v. Pemerintah diharapkan dapat memberi kebijakan dalam mengarahkan agar projek-projek yang dirancang dan direka-yasa di Indonesia dapat ditangani oleh jasa konstruksi nasional, dengan memanfaatkan secara maksimal seluruh sumber-daya (manusia, peralatan, material, dan teknologi dari dalam negeri) tanpa melalui proteksi

w. Kesadaran sebagai anggota profesi yang direkomendasikan oleh asosiasi 
profesi Arsitek (IAI), cenderung sangat rendah, kondisi ini harus dapat diantisipasi, khu-susnya dalam persaingan global menda-tang, dimana setiap pelaku profesi diharapkan telah memiliki sertifikasi profesi-onal-internasional dalam bidangnya.

\section{DAFTAR PUSTAKA}

Astuti SA. Odang (1992), F. Silaban Arsitek dan Karyanya: Dalam Konsep dan Karya, Nova, Bandung

Baldwin, J. (1985), Environmental Planning and Management, Westview Press, Boulder

Budihardjo, Eko (1991), Arsitek Bicara tentang Arsitektur Indonesia, Alumni, Bandung

Budihardjo, Eko (1991), Jatidiri Arsitektur Indonesia, Alumni, Bandung

Budihardjo, Eko (1991), Мепији Arsitektur Indonesia, Alumni, Bandung

Budiman, J.K. (1995), Design and Build, Majalah Konstruksi

Brolin, Brent.C. (1976), The Failure of Modern Architecture, Van Nostrand Reinhold Company

Fergusson (1989), The Conctruction Industry Research and Information Association, United Kingdom dari CIRIA

Handler, Benyamin (1970), System Approch to Architecture,American Elsevier,Pub.Co.Inc, New York

Ligo, Larry.L. (1984), The Concept of Function in Twentieth Architecture Critism, Umi Research Press, Michigan

Miller, (1990) The Conctruction Industry Research and Information
Association, United Kingdom dari CIRIA

Norberg-Schultz, Christian (1977), Intensions in Architecture, The MIT Press, Cambridge-Massachusetts

O'Connor and Davis (1977), Journal of Construction Engineering and Management, ASCE

Papanek, Victor (1972), Design for The Real World, Random House Inc., Toronto

Pedju, Mochtar, Ary (2005), dpr, Bank, dan Pembangunan Projek, Majalah Konstruksi

Pedju, Mochtar, Ary (1993), Pengelolaan Pembangunan Projek Konstruksi Berskala Besar, Majalah Konstruksi

Raskin, Eugene, (1954), Architecturally Speaking Speaking, Reinhold Publishing Corporation

Sachari, Agus, (1986), Seni Desain \& Teknologi, Antologi Kritik Arsitektur, Pustaka, Bandung

Susanto, A.B. (1996), Upaya Memperkecil Jaring Konsultan Asing, Majalah Konstruksi. 